\title{
Impact of Relationship Education Training on the Management of Marital Discords Among Young Couples in Colleges of Education in Nigeria
}

\author{
Jummai Grace TABAT, Ph.D \\ Department of Home Economics \\ Kaduna State College of Education, Gidan Waya
}

\begin{abstract}
This research work investigated impact of Relationship Education Training on the Management of Marital Discords among Young Couples in Nigerian Colleges of Education. Experimental research design was adopted for the study. The population for the study comprised of all young couples in the 85 accredited Colleges of Education in Nigeria. Eight Colleges were used as sample schools for the study and a total of 240 conflicted and devitalized young couples in the eight Colleges of Education served as sample size for the study; 120 served in the experimental group and another 120 for control group. Three sets of research instrument were developed and used for this study (A baseline questionnaire for young couples so as to assist the researcher in selecting the devitalized and conflicted couples for the study, Relationship Education Training Manual, and a Pre-test Post test questionnaire were also used in answering the research questions and also test the null hypotheses. The researcher employed the services of four (4) first degree holders as research assistants. This is because the study covered a large geographical location that will take a lot of time for the researcher to cover and to also have a successful and smooth conduct of the training and the administration of the research instrument. Descriptive statistics (Frequency, Percentage and mean) were used in answering the research questions. The Null hypotheses were tested using Independent t-test statistics at 0.05 Alpha level of significance. Findings from the study revealed that most of the respondents were ignorant and lack adequate knowledge of Relationship-education. Based on the results, the following recommendations were made: Remuneration, good salary, job satisfaction of social workers and counselors should be enhanced and regularly reviewed with full monitoring by the government officials. Training and retraining of counselors in the area of marriage relationship education should be organized regularly by the government and religious leaders as a way of updating the marriage counselors with useful knowledge in the area of relationship-education.
\end{abstract}

Key Words: Marriage, Relationship education training, Marital discord and Young couples

DOI: $10.7176 /$ RHSS/9-11-10

Publication date:June $30^{\text {th }} 2019$

\section{Introduction}

Marriage is seen as a social and universal institution founded on and governed by the social and religious norms of the society. It is usually contracted amidst joy, happiness and merry making among couples, family members and friends (Alex, 2007). No wonder for a stable and happy marriage, parents play some traditional roles in choosing marriage partners for their children. In many cultures, preliminary investigations and enquiries were carried out by parents and relations of both the bride and groom on whom their children would marry. This was followed by the fulfillment of all necessary traditional rites before the actual wedding day. This is because marriage was regarded as an alliance between two families, rather than just between the two individuals. It also served as the basis where both parents and even the communities were saddled with the responsibilities of building up honest, responsible, dedicated and obedient children (Alex, 2007; Tabat, 2015).

However, marriages nowadays are becoming more transformed thereby, making the rich values under strain. In other words, the institution of marriage has been changing and will continue to change particularly among young couples if nothing is done. It should be noted that globalization has failed the family; as such it has eroded strong family values and replaced it with commercialized relationships thereby inflicting a heavy blow on the marriage institution worldwide. In addition to these, a wide range of social ills might have contributed to the weakening of marriages and have put huge demands on the present generation, especially among young couples into serious problems. These may include mass media, western education, migration, pornography, unemployment and poverty, the erosion of fidelity in marriage, and many other social phenomena. All these, plus over socialization and promiscuous nature of societies are causing young couples becoming less tolerant, and at the first sign of a flaw, marital discord erupts.

Marital discord can be defined as an active quarrelling or conflict resulting from misunderstanding between a husband and a wife (DeMaris, 2000; Waite \& Gallagher, 2000). Discord among young couples is a strong predictor of marital dissolution that usually occurs due to general lack of emotional fulfillment (Ononuju, 2004). Coontz, (2005) reported that marital discord occurs because the society has a set of unwritten norms that 
guide marital relationships and the responsibilities of the men and women in those relationships. Amato and Hohmann-Marriot, (2007) and Bhatt (2008) opined that any marriage contracted without proper guidance and planning may likely result in discord. As such, when effective and adequate relationship education training are giving to young couples and to-be couples, this may help in managing some of the marital discords that may likely occur in their marital life.

Relationship education is an educational approach that teaches skills, strategies and attitudes associated with success in marriage relationships, as well as helping couples communicate better and improve their ways of handling conflict at homes (Markman, Stanley, Blumberg, Jenkins, \& Whitely, 2004). Dion (2005) described Relationship education training as marriage intervention which provides necessary knowledge and skills to couples on how to respond positively to family issues, related problems and problem-solving strategies for coping. It as knowledge based skill training which helps in Providing couples with tools to improve communication, bonding, and conflict resolution, increases relationship satisfaction and ultimately can help sustain marriages (Eisenberg, 2013).

Young couples are seen as two persons of the opposite sex who agreed to live together for the rest of their life time as husband and wife and whose marriage life is between one to ten (1-10) years, life experience, and maturity are considered as early, tender, having little experience (Adams, 2010; Tabat, 2015). Looking at how in-experienced young couples are, the chances of experiencing discord are high. The knowledge of relationship education training is seen as a relevant tool for managing such marital discord, which this research study intends to investigate.

\section{Statement of the Problem}

The family institution (marriage) which is the basic unit of social organization is being threatened by marital discord particularly among young couples in Nigeria. Lack of adequate and effective discord management skills is considered central to this threat. Coontz (2005) opined that any marriage contracted without proper guidance and planning may likely result in discord. Marital discords in the study areas are causing serious damage in many homes as some of these parents produce off-springs that may likely pose danger to the society; this could be seen where children have become school drop-outs, some have given birth to out-of wedlock children while others indulged in other antisocial activities (Namka, 2008).

Also, marital discord among young couples in the study areas has substantially contributed to social condition that threatened the foundation of the society, culture and potential for economic prosperity including dramatic increase in delinquent and illegal behaviours; juvenile and adult incarceration, illegal drug use, and risky sexual activities, declining academic performance, physical and mental health concerns and increase in poverty are prominent in many homes. This has ravaged and devastated many families causing great distress for couples thereby putting them at risk for developing higher levels of depression and anxiety and other diseases like hypertension (Tabat, 2015).

Frequent occurrence of marital cases in the study area (which includes infidelity, mistrust among couples, sexual assaults, lack of commitment and selfishness among couples and many more) if allowed to go on uncontrolled, will not only affect the couples concerned but the whole society.

Similarly, young couples and to-be couples in the study area may be ignorant of the significance and impact of relationship-education training on the management of marital discord. Therefore, this research study was carried out in order to find out the impact of relationship education training on the management of marital discord among young couples in Colleges of Education in Nigeria.

\section{Research Questions}

The following research questions were answered:

1. What are the causes of marital discords among young couples in Colleges of Education in Nigeria?

2. What are the impacts of marital discords on the psychosocial development of young couples in Colleges of Education?

3. What are the impacts of Relationship-education training on the management of marital discords of young couples in Colleges of Education in Nigeria?

\section{Research Hypotheses}

This study formulated and tested the following null hypotheses:

Ho1. Marital discord has no significant impacts on the psychosocial development of young couples in Colleges of Education

Ho2. Relationship-education training has no impact on the management of marital discords of young couples in Colleges of Education in Nigeria. 


\section{Methodology}

Experimental research design was adopted for the study. A total of Eighty five (85) accredited Colleges of Education in Nigeria was used. Eight (8) out of the eighty five Colleges was used as sampled Colleges for the study. Purposive sampling technique was adopted in selecting two hundred and forty (240) devitalized and conflicted young couples from the eight sampled Colleges to serve as sample size for the study. These subjects were randomly selected and assigned to experimental and control groups. The essence of using random sampling technique was to ensure fairness, balance and objectivity in selection.

A structured questionnaire was developed by the researcher and was also validated by experts. The questionnaire was designed to elicit quantitative information to address the set research questions and the hypotheses. A reliability coefficient of 0.89 was obtained. Data analyzed were based on two hundred and forty copies of the questionnaire that were correctly filled and returned. The questionnaire contained information on types, causes, consequences, frequency and couples awareness of marital discord. The questionnaire was designed in a 4-point rating scale format with Strongly Agree = 4, Agree =3, Disagree =2 and Strongly Disagree $=1$. In the course of answering the research questions, "strongly agree' and agree" were classified as "agree or significant". Similarly, "strongly disagree" and "disagree" were also classified as "disagree or insignificant". Descriptive statistics (frequency, mean and standard deviation) was used in analyzing the research questions. The hypotheses were tested using t-test statistics at 0.05 Alpha level of significance. Four trained research assistants were employed who helped in the distribution and collection of the filled questionnaire.

\section{Results and Discussion}

Research Question One: What are the causes of marital discord among young couples in Colleges of Education, Nigeria?

The analysis of data generated to determine the causes of marital discord among young couples of Colleges of Education, Nigeria is presented in Table 1.

Table 1: Analysis of Respondents on Causes of Marital Discord

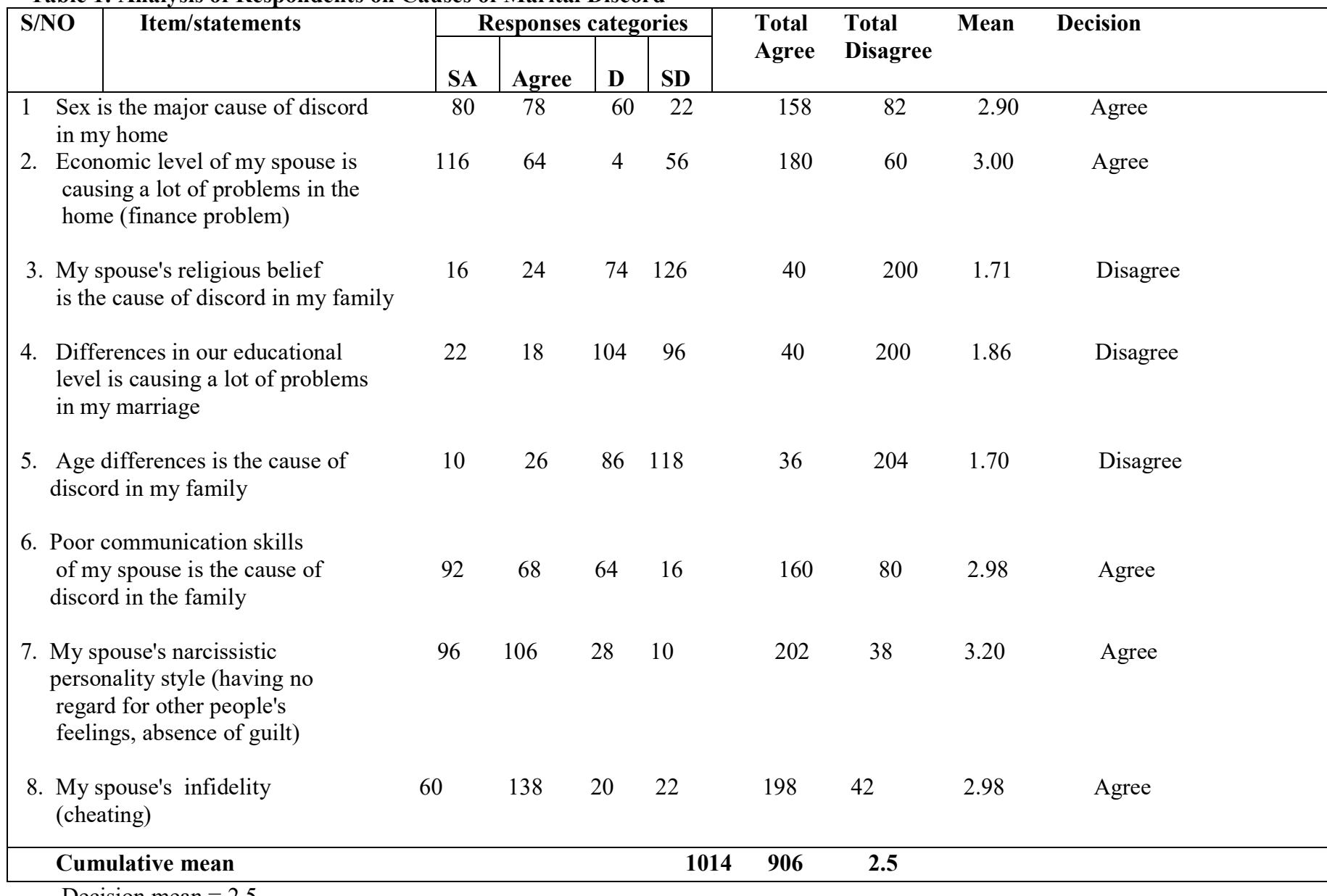
Decision mean $=2.5$ 
Table 1 results revealed that 1014 was the total scores of couples who agree that sex, finance problem, poor communication skills, narcissistic personality style of spouse and infidelity were some of the major causes of marital discord while those who were in disagreement had a total score of 906. Also the cumulative mean was $2.6>2.5$ benchmark of agree. This implied that sex, finance problem, poor communication skills, narcissistic personality style of spouse and infidelity were the main causes of marital discord among young couples of Colleges of Education in Nigeria.

Research Question Two: What are the impacts of marital discord on the psychosocial development of young couples in Colleges of Education?

The analysis of data generated to determine the impacts of marital discord on the psychosocial development of young couples in Colleges of Education is presented in Table 2

Table 2: Analysis of Respondents on impacts of Marital Discord

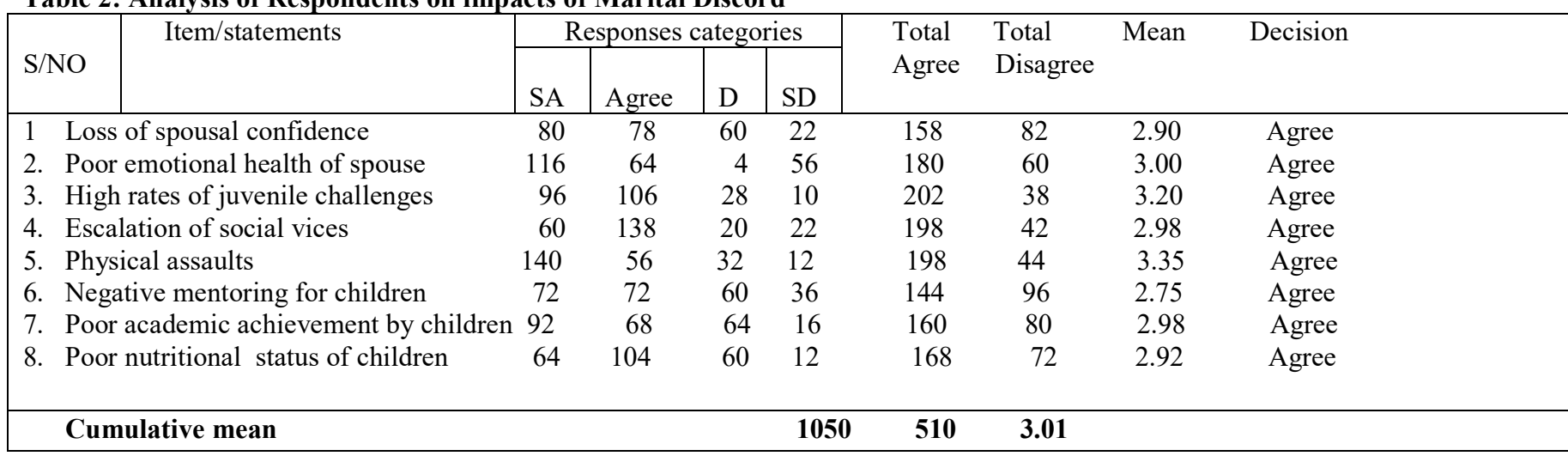

Decision mean $=2.5$

Table 2 showed results on analysis of Respondents on impacts of marital discord among young couples. The result indicated that all the respondents agreed that loss of spousal confidence, poor emotional health of spouse, high rates of juvenile challenges, escalation of social vices, physical assaults, negative mentoring for children, poor academic achievement by children and poor nutritional status of are some of the negative impacts of marital discords among young couples.

Research Question Three: What are the impacts of relationship education training on the management of marital discord among young couples in Colleges of Education, Nigeria?

The analysis of data generated to determine the impacts of relationship education training on the management of marital discord among young couples in Colleges of Education is presented in Table 3

Table 3: Analysis of Respondents on Impact of Relationship Education on the Management of Marital Discord (Control Vs Experimental groups)

\begin{tabular}{|c|c|c|c|c|c|c|c|c|c|c|}
\hline \multirow{2}{*}{$\mathrm{S} / \mathrm{No}$} & \multirow[t]{2}{*}{ Item/statements } & \multirow[b]{2}{*}{ Groups } & \multicolumn{4}{|c|}{ Responses categories } & \multirow{2}{*}{$\begin{array}{l}\text { Total } \\
\text { Agree }\end{array}$} & \multirow{2}{*}{$\begin{array}{l}\text { Total } \\
\text { Disagree }\end{array}$} & \multirow[t]{2}{*}{ Mean } & \multirow[t]{2}{*}{ Decision } \\
\hline & & & SA & Agree & $\mathrm{D}$ & SD & & & & \\
\hline \multirow{2}{*}{\multicolumn{2}{|c|}{ 1. Positive spousal confidence }} & CONTROL & 20 & 20 & 40 & 40 & 40 & 80 & 2.09 & Disagree \\
\hline & & EXPT & 50 & 49 & 10 & 11 & 99 & 21 & 2.90 & Agree \\
\hline \multirow{2}{*}{\multicolumn{2}{|c|}{ 2. Good marital communication }} & CONTROL & 7 & 14 & 58 & 41 & 21 & 99 & 1.89 & Disagree \\
\hline & & EXPT & 68 & 32 & 14 & 6 & 100 & 20 & 3.00 & Agree \\
\hline \multirow{2}{*}{\multicolumn{2}{|c|}{ 3. Mutual Respect between Partners }} & CONTROL & 10 & 12 & 18 & 80 & 22 & 98 & 1.60 & Disagree \\
\hline & & EXPT & 63 & 37 & 12 & 8 & 100 & 20 & 3.23 & Agree \\
\hline \multirow{2}{*}{\multicolumn{2}{|c|}{ 4. Increase honesty between Partners }} & CONTROL & 8 & 22 & 28 & 62 & 30 & 90 & 1.80 & Disagree \\
\hline & & EXPT & 48 & 52 & 9 & 11 & 100 & 20 & 3.14 & Agree \\
\hline \multirow{2}{*}{\multicolumn{2}{|c|}{ 5. Less argument between partners }} & CONTROL & 15 & 20 & 30 & 55 & 35 & 85 & 1.96 & Disagree \\
\hline & & EXPT & 43 & 59 & 5 & 13 & 102 & 18 & 3.10 & Agree \\
\hline \multirow{2}{*}{\multicolumn{2}{|c|}{ 6. Good child mentoring }} & CONTROL & 20 & 18 & 52 & 30 & 38 & 82 & 2.23 & Disagree \\
\hline & & EXPT & 36 & 36 & 30 & 18 & 72 & 48 & 2.75 & Agree \\
\hline \multicolumn{3}{|c|}{ Cumulative mean } & & & $\begin{array}{l}186 \\
553 \\
\end{array}$ & $\begin{array}{l}534 \\
167 \\
\end{array}$ & $\begin{array}{l}1.9 \\
3.0 \\
\end{array}$ & & & \\
\hline
\end{tabular}

Decision mean $=2.5$ 
The data in Table 3 showed the results for both experimental and control groups respectively on impact of relationship education on the management of marital discords among young couples in Colleges of Education. The results revealed that the cumulative mean scores for the experimental group were higher (3.0) than that of the control group (1.9). This can also be compared with the total agreed and disagreed of the two groups. The total agreed for the experimental group was 553 while that of the control group was 186 . The calculated mean for the experimental group was $3.0>2.5$ benchmark of agree while that of the control group was $1.9<2.5$ benchmark. This implied that relationship education training had impact on the management of marital discords among young couples.

Test of Null Hypotheses:

Null Hypothesis One: Marital discord has no significant consequences on the psychosocial development of young couples in Colleges of Education

Independent t- test statistics was used to test this hypothesis and the results are shown in Table 4

Table 4: Analysis of respondents on impacts of marital discord on young couples (Experimental vs. Control)

\begin{tabular}{|c|c|c|c|c|c|c|c|c|c|}
\hline Variable & Groups & $\mathrm{N}$ & Mean & SD & std.err & df & $\begin{array}{c}\mathrm{t} \\
\text { calculated }\end{array}$ & $\begin{array}{c}\mathrm{t} \\
\text { critical }\end{array}$ & Sig (p) \\
\hline \multirow[t]{2}{*}{$\begin{array}{l}\text { Impacts of } \\
\text { marital discord }\end{array}$} & Experimental & 120 & 9.7833 & 3.41031 & .44027 & \multirow[b]{2}{*}{118} & \multirow[b]{2}{*}{3.603} & \multirow[b]{2}{*}{1.96} & \multirow[b]{2}{*}{0.000} \\
\hline & Control & 120 & 7.7667 & 2.67675 & .34557 & & & & \\
\hline
\end{tabular}

Calculated $\mathrm{p}<0.05$, calculated $\mathrm{t}>1.96$ at df 118

Table 4 results revealed that, calculated p value of 0.000 was lower than 0.05 alpha level of significance and also the calculated $t$ value of 3.603 was greater than 1.96 critical $t$ value at $\mathrm{df} 118$. The calculated mean value of the two groups also confirms this difference where 9.7833 and 7.7667 were recorded for experimental and control groups respectively, their respective standard deviations also indicated this difference. The null hypothesis which stated that marital discord has no significant impacts on the psychosocial development of young couples was therefore rejected.

Null Hypothesis Two: Relationship Education training has no significant impact on the management of marital discords of young couples in Colleges of Education in Nigerian.

Independent t- test statistics was used to test this hypothesis and the results are shown in Table 5

Table 5: Analysis of respondents on impact Relationship-education training

\begin{tabular}{|c|c|c|c|c|c|c|c|c|c|}
\hline Variable & Groups & $\mathrm{N}$ & Mean & SD & std.err & $\mathrm{df}$ & $\begin{array}{c}\mathrm{t} \\
\text { calculated }\end{array}$ & $\begin{array}{c}\mathrm{t} \\
\text { critical }\end{array}$ & $\begin{array}{l}\text { Sig } \\
\text { (p) }\end{array}$ \\
\hline \multirow{2}{*}{$\begin{array}{l}\text { Impact of Relationship-education } \\
\text { training }\end{array}$} & Experimental & 120 & 10.1833 & 3.33696 & .43080 & \multirow[b]{2}{*}{118} & \multirow[b]{2}{*}{2.924} & \multirow[b]{2}{*}{196} & \multirow[b]{2}{*}{0.004} \\
\hline & Control & 120 & 8.5167 & 2.89061 & .37318 & & & & \\
\hline
\end{tabular}

Calculated $\mathrm{p}<0.05$, calculated $\mathrm{t}>1.96$ at $\mathrm{df} 118$

The results in Table 5 showed that the calculated $p$ value of 0.004 was lower than the 0.05 level of significance while the calculated $t$ value of 2.924 was greater than 1.96 critical $t$ value at df 118 . Also, calculated mean for experimental group and that of the control group were 10.1833 and 8.5167 respectively and this has confirmed that. The standard deviation of the two groups also confirmed this difference which implied that relationship education training had impact on young couples who went through the training than those who did not. The null hypothesis which stated that Relationship-education training has no impact on the management of marital discords of young couples was therefore rejected.

\section{Discussions of Major Findings}

The research study was to determine the impact of relationship education training on the management of marital discord among young couples in Colleges of Education, Nigeria. Two groups of respondents were used in relation to the causes, impact and consequences of marital discord among young couples. In order to achieve the stated objectives of the study, two null hypotheses were postulated and tested. The interpretations of both the descriptive and inferential analyses were done, and detailed discussions of the findings were enunciated thus: 
The findings in Table 2 and 4 revealed that loss of spousal confidence, poor emotional health of spouse, high rates of juvenile challenges, escalation of social vices, physical assaults, negative mentoring for children, poor academic achievement by children and poor nutritional status are some of the impacts of marital discords among young couples in Colleges of Education.

Brody (1994); Erel and Burman (1995) pointed out that marital discord is associated with poorer parenting, poorer child adjustment problematic attachment to parents, increased likelihood of parent-child conflict, and conflict between siblings (Amato, 1996; Owen \& Cox, 1997). Marital discord is also associated with negative health and mental health outcomes for children, including depression, poorer health, poorer academic performance, and increased problems with aggression (Fincham \&\& Bradbury, 1993). Marital discord has negative influence on children; in fact it is associated with increased risk of future marital discord for offspring (Grych \& Fincham, 2001). Children from discord family naturally lack interest and love for others. They grow up to be aggressive because their growing home has never showed them love; hence aggression is all they know. Most of them are never law abiding as they never saw law and order in their homes at their growing stage (Ononuju, 2004).

The findings in Table 3 and 5 revealed that relationship education training had significant impact on the management of marital discord among young couples who went through relationship-education training than those who did not. These differences were revealed in the mean scores and standard deviation of the two groups of respondents. The experimental group indicated high positive impact on spousal confidence, good marital communication, mutual respect between partners, increase honesty between partners, less argument and good child mentoring while that of the control group was negative. This implied that relationship education training has positive impact on the management of marital discord.

This finding is in agreement with Dion (2005) and Howell, (2007) who reported that, Relationship Education is a skill-based training which "provide support, information and education to couples on how to develop healthy relationships and marriages," Eisenberg and Gordon, (2009) also noted that Relationship Education is a knowledge based skill training which helps in Providing couples with tools to improve communication, bonding, and conflict resolution increases relationship satisfaction and ultimately can help sustain marriages. Relationship education training provides a road map and usable skills for sustaining healthy relationships that are an ongoing source of love, pleasure, happiness, and fulfillment for both partners (Eisenberg, 2011).

\section{Conclusion}

Based on the findings of this study, it can be concluded that relationship education training has positive impact on the management of marital discord among young couples. Hence, couples who participated in the training exhibited high positive impact on spousal confidence, good marital communication, mutual respect between partners, increase honesty between partners, less argument and good child mentoring. Relationship education training has invariably improved marital relationship among couples in Colleges of Education.

\section{Recommendations}

Based on the findings it was recommended that:

1. Specialists (Family and Child Specialists) should find a way of organizing regular talk-shows, seminars and workshops in schools and colleges where adequate knowledge and positive skills in handily marital problems like sex issues, communication, finance and infidelity be discuss.

2. Religious leaders should enact effective laws on all intending couples on the need to undergo thorough and effective marital training before getting marriage so as to equip them with adequate skills in managing marital discord.

3. Remuneration, good salary, job satisfaction of social workers and counselors should be enhanced and regularly reviewed with full monitoring by the government officials so as to boost their morale in discharging their duties.

4. Training and retraining of counselors in the area of marriage relationship education should be organized regularly by the government and religious leaders as a way of updating the marriage counselors with useful knowledge in the area of relationship-education.

5. Curriculum planners should include Relationship-education training program in the curriculum of postprimary and tertiary schools as some of this couples married within this period of schooling so as to enable them acquire the knowledge and skills before living.

6. Couples should be well matured in age and experienced in marital issues before contracting any marriage so as to avoid premature divorce resulting from complications from discords. Couples who are experiencing intense marital conflicts should be open to share their ordeal doing that will help in addressing the problem and serve as a guide to other couple that may likely experience similar problems in their marriage lives. 
Reference

Adams, D. W. (2010). "Goals of Relationship Education," PAIRS Foundation, Hollywood, FL. Cited with permission. Http://participants pair.com/eqcouple.php. Retrieved 29/01/2014.

Alex, k (2007). Relationships: Marrying Too Young is Fraught with Problems, Experts Say http://www.divorce360.com/divorce-articles/statistics/us/marrying-too-young-can-causedivorce. aspx?artid=552. Retrieved 25/2/2015

Amato, Paul R. \& Hohmann-Marriot B. (2007). "A Comparison of Low-Distress Marriages that End in Divorce.” Journal of Marriage and Family. 69(13) 621-6

Amato, P.R. \& Rogers J. S (1997). "A Longitudinal Study of Marital Problems and Subsequent Divorce." Journal of Marriage and Family 59(3) 612-624.

Bhatt, A (2008). Complete Information on Marriage and its Various Forms http://www.preservearticles.com/201101183517/marriage-and-its-various-forms.html. Retrieved $14 / 11 / 2013$

Coontz (2005). Past, Present, Future of Marriage. http://stephaniecoontz.com/articles/article23.htm. Retrieved $\underline{25 / 11 / 2014}$

DeMaris, A (2000). "Till Discord Do Us Part: The Role of Physical and Verbal Conflict in Union Disruption." Journal of Marriage and Family. 62(3)683-692.

Eisenberg, S (2011). "Revolutions of a Lifetime at Home and Abroad," Fatherhood Channel.

Eisenberg, S (2013). "The ABC's of Marriage and Relationship Education," Coalition for Divorce Reform.

Fincham, F.D. \& Bradbury, T.N. (1993). Marital Satisfaction, Depression, and Attributions: A Longitudinal Analysis. Journal of Personality and Social Psychology. 64(3) 442-452.

Grych, J.H. \& Fincham, F.D. (Eds.) (2001). Interparental Conflict and Child Development: Theory, Research, and Applications. New York: Cambridge University Press.

Howell, P. (2007). Marriage Education: An Important Investment in Cultural Change. The Therapist. 5(2) 45-53.

Markman HJ, Stanley SM, Whitton SW, (2004). Maybe I do: Interpersonal Commitment and Premarital or Nonmarital Cohabitation. Journal of Family Issues ;25(4):496-519.

Namka, L. (2008). A Tribute to the most Marvelous Virginia Satir. http://www.angriesout.com/satir.htm. Retrieved 8/3/2007

Ononuju, N.J (2004). The Family and Parenting in Nigeria's Social Development. Polly Amadi Publication, 34Madumere street, Nigeria

Waite, E.J \& Gallagher, M (2000). The Case for Marriage: Why Married People are Happier, Healthier and Better off Financially. New York; Broadway. 